\title{
Library and Education: Panacea for Sustainable Development in Nigeria
}

\author{
Nicholas Mfangu Tyonum ${ }^{1}$ and Perpetual AmarachiEzeogu ${ }^{2}$ \\ ${ }^{1}$ Benue State University Library, Makurdi \\ ${ }^{2}$ Department of Library and Information Science,Nnamdi Azikiwe University, Awka \\ E-mail: tyonik@yahoo.com, amarapet@yahoo.com
}

\begin{abstract}
One important resource for achieving the goals and objectives of education is the library. This paper discussed the role of library. It examined the relationship between the library and education; the relevance of the former to the latter; Importance of library and education for sustainable development in Nigeria. This paper also highlighted the challenges of library and education and made recommendations. Finally, this paper emphasized the need to reposition and revamp our libraries and the entire educational system in order to make much progress towards the attainment of vision 2020.
\end{abstract}

Keywords: Library, Education, Sustainable Development.

\section{I.INTRODUCTION}

No meaningful and effective teaching and learning can take place without information and information resources. Libraries of all types, acquire, process, organize, store and provide information to users in various forms. Everyone needs information for survival. Information is power, Information gives knowledge, no wonder it is viewed as a valuable national resource useful for personal, community, economic, educational, cultural, social and technological development.

Information which is the only preoccupation of libraries is a necessary ingredient in life. In this information age, one must be attuned with reliable and up-to-date information for rational decision-making, enlightenment and all round development. With the advent of information and communication technology (ICT), libraries not only provide information traditionally but also in electronic forms, hence bibliographic databases. Full text documents and digital library collections are always available to users.

Information made available by libraries plays a vital role in educational planning and has become a global phenomenon of great importance and concern in all spheres of human endeavour, especially in the education sector. It is the integral part of the main plan and achievement of educational activities.

For education to be effective and efficient, it is essential to have well equipped libraries. Ezekwe and Muokebe (2012) opined that well stocked libraries with books and other digital materials are best legacies that the human race can claim to have, for in the words of Cicero "A room without books is a body without a soul". This means that any educational institution without a library is not worth its salt.

Library and education are two sides of a coin, they cannot be isolated from each other. Hence, the impact of library services is greatly felt in schools, colleges and universities since libraries permeate the entire fabric of the educational system. Education is recognized as one of the most fundamental building blocks for human development. Its importance in nation building cannot be over emphasized. A major outcome of education is sustainable development. No nation can grow beyond its educational system. Education is the bedrock for growth, the key to development, the greatest investment and asset and enhances sustainable development in a nation and the library has a great role to play towards the realization of the broad goals of education. Hence the topic; Library and education: panacea for sustainable development in Nigeria.

\section{A.Library}

A library is an organized collection of print and nonprint resources for use in order to satisfy the information needs of its clienteles. A library is an information centre whose function is to acquire, process, organize, store, retrieve and disseminate information to users.

Aina (2004) stated that a library is concerned with the collection, processing, storage and dissemination of recorded information for the purpose of reading, study and consultation. As a veritable source of information a library can be described as the key to agricultural development, the rocky foundation for an effective educational system, the secret behind the success of many private sector, organizations and sound government parastatals, an instrument of conflict prevention and resolution, a tool for administrative effectiveness; a requirement for all health workers and operators of medical databases whether in orthodox or in alternative medicine, the main weapon of security operatives, a magnetic attraction for investors, added value to services and products and promotion of international trade; and mandatory requirement for planning and provision of amenities, (Ifidon \& Ifidon, 2007). 


\section{B.Education}

Education is the process of developing an individual physically, spiritually, socially, mentally, emotionally and orally for the well being of the individual and that of the society in which he belongs.

Similarly Ezekwe and Muokebe (2012) opined that education is the preparation of man for life. The concept of education encompasses teaching and learning of specific skills and also imparting of culture from generation to generation.

Alumode (2013) observed that education is a means by which an individual acquires the many physical and Psychospiritual capabilities demanded by socio-cultural environment within which one is groomed to live and function. Ifidon and Ifidon (2007) defined education as the process of training the mind, acquiring skills and developing a refined culture all of which prepares the citizenry to meet life challenges and teaches them how to solve problems.

\section{II.SUSTAINABLE DEVELOPMENT}

Sustainable development means the overall change and improvement in the society as related to the individual in the society as related to the progress in the social, political, religious and economic structure of the nation. A major outcome of education is sustainable development.

Shah (2012) noted that sustainable development encompasses a number of areas and stands as the idea of environmental, economic and social progress and equity, all within the limits of the world's natural resources. Sustainable development not only meets the needs of present generation but also those of the future generation. In other words, it is the development that guarantees a better quality of life for everyone, now and for generations to come.

\section{A.Role of Libraries}

Libraries whether academic, school, Public, national or special perform the following functions

i) Information services: A very important role of the library is to provide information sources which will help augment ideas collected from other sources. Information is an essential element in the communication process. With the advent of ICT, this role is facilitated, hence users can access information via the internet to update the knowledge and keep abreast of current trends.

ii) Educational role: Educational services is closely related with information services because when a person is informed, he is equally being educated. Libraries ensures lifelong education by providing various information resources. They also support education by providing supplementary textbooks, reference materials and even non-print materials.
According to Ejimkonye, Nwoguand and Obiagwu (2005) the library performs its educational role at four levels: formal, informal, non-formal and propaganda. At the formal level, the academic library identifies itself with the goals and objectives of its parent institution by providing curriculum-oriented materials. At the informal level, the public library allows users to read whatever materials they want to read and these materials contain educational value. The non-formal level is directed to those who are not reading for an examination per se but who want to improve on their different trades like carpentry, mechanics, electricity among others.

At the propaganda level, libraries are used for propagate ideas, information and point of view. They can be veritable agents for the diffusion or dissemination of beliefs, doctrines and practices.

iii) Research role: Research which is an enquiry to discover existing knowledge for the building of theory and solving society problems is an essential activity in the library. The library organizes and presents information, materials, thus saving the researchers' time in retrieving information.

They also provide publications of previous research findings for subsequent references by other researchers.

iv) Cultural services: The library is the chief centre for cultural revival. It is the centre of all cultural activation because it actively promotes participation and appreciation of arts literature which is part of cultural heritage is one of the areas stock materials highlight.

v) Self development: People can develop themselves by going to the library for independent studies. Individualized instruction can take place in the library without the help of any teacher yet this ensures expansion of knowledge.

vi) Access to knowledge: Libraries pool resources together for the maximum accessibility and usability by the potential users. Information is power and information brings knowledge. Hence the library helps its patrons to access such information and knowledge with ease.

vii) Training and learning media: The library is an indispensable training and learning laboratory. Some libraries are training media for manpower development. For instance the business library is used by Institute of Chartered Accountants of Nigeria (ICAN) to train accountants and even law libraries for training lawyers etc.

viii) Recreational role: Users can read in the library at leisure for pleasure. Libraries provide various information media (print and non-print) that are used for recreational activities. 


\section{B.Library and Education}

Library and education are two sides of a coin; hence they cannot be isolated from each other. The library has since ages been associated with education.

The impact of library services in the educational sector cannot be overemphasized. These impacts are greatly felt in colleges and universities even in informal setting since libraries permeate the entire fabric of educational system.

Ejimkonye, Nwogu and Obiagwu (2005) observed that the library is a recognized and essential resource centre which no student can afford to dispense with, if he wants to attain his academic goals. Libraries are established for educational purposes. No education can win recognition without organized and well established library. No wonder, the national Universities Commission (NUC) critically evaluates the library before accrediting any education institution.

UNESCO as a body encourages education and development of man has similar objectives of libraries as essential components of modern life. It reads:

- To help the various people know each other better

- To give a new stimulus to popular education

- To promote the ideal of equal opportunities for everyone and to share in cultural life

- To preserve and protect the immense legacy of books bequeathed by man to man and to give all nations of the world access to the book published by every other nation.

Library fosters self-education and stimulates educational growth. Education generally depends on the information resources available in the library. Any effective and qualitative education depends on the library for its teaching, learning, research and expansion of knowledge. Edom (2006) stated that effective use of library is the bedrock of academic excellence. In analyzing the relationship between library and education, Nwosu (2000) stressed that an academic library is the singular most important resource in the pursuit of general goals and objectives of the institution of higher learning. She further stated that higher education would be elusive without the libraries. This indispensable role has been reflected in many description of the library in academics such as "the pivot of knowledge," "the educative aorta of the institution", "the heart of the institution".

Imparting of cultural heritage from generation to generation which is a major role of education is made possible because library is the centre for all cultural activities and conserve knowledge and ideas passed from generation to generation and the materials are arranged for present and future use.

In fact, the library is to education, as the heart is to the body. As the heart pumps blood to the body so does the library pump information and learning materials to education. Hence it is an indispensable part of the educational sector.

\section{III.LIBRARY AND EDUCATION FOR SUSTAINABLE DEVELOPMENT}

As earlier pointed out, the library fosters self education and stimulates education growth. Any effective and qualitative education depends on the library for its teaching, learning, research, consultation and expansion of knowledge. Similarly, Edom (2006) stated that effective use of library is the bedrock of academic excellence. Thus, the library is the most important resource in the pursuit of the broad goals and objectives of any educational institution.

On the other hand, education is the most sociological tool for sustainable development in any nation. It is on this platform that the Federal Republic of Nigeria (FRN) in her National Policy on Education stated that:

Education shall continue to be highly rated in the national development plans because education is the most important instrument of change; any fundamental change in the intellectual and social outlook of any society has to be proceeded by an educational revolution (FRN, 2004)

Through education, people's minds think positively and by extension, they can take care of themselves and also a nation's resources can be harnessed.

Education as a long-term investment guarantees a nation its bright future. The technological advancement in the world today is attributed to education, thus any country yearning for sustainable development must accord education a priority. Any nation that is intellectually bankrupt will certainly be socially, politically and economically bankrupt.

Qualitative and functional education enhances individuals' ability to survive in the contemporary society and fosters sustainable socio-economic development. Ifidon and Ifidon(2007) demonstrated that the principal actors in the education industry are teachers, librarians, parents, youths, the government and society at large. They further stated that education is a tool for growth and development. Since no modern society can function without an intensive use of books and information and libraries guarantee improved information services and national development. Therefore library and education are panacea for sustainable development of any nation.

\section{A.Challenges of Libraries}

Despite the relevance of libraries to education and the nation at large, regrettably libraries in Nigeria are facing a lot of challenges that limit their effective services. These challenges include: 
i) Poor funding

ii) Inadequate qualified staff

iii) Inadequate ICT facilities

iv) Epileptic power supply

v) Inadequate research materials

vi) Outdated collections

vii) General low perception of the relevance of libraries.

\section{B.Challenges of Education}

i. $\quad$ Poor funding- Embezzlement of fund meant for educational development purposes

ii. Inadequate qualified teachers

iii. Ill-motivated teachers

iv. Inadequate education facilities such as well equipped libraries, laboratories etc.

v. Dilapidated infrastructures

vi. Politics- The formulation and implementation of educational programmes in Nigeria are becoming increasingly politicized at all levels of government.

vii. Treating education with disdain.

viii. Lack of research and development

\section{IV.CONCLUSION}

Libraries are essential to our economic well being, the improvement of learning, meeting the challenges of information overload. Education is core to sustainable national development. If Nigeria can pay serious attention to education and libraries, she will overcome some of her problems and become one of the top 20 economies in the world in the year 2020.

\section{V.RECOMMENDATIONS}

From the above problems bedeviling our educational sector and libraries, this paper recommends that:

i. Government should provide adequate funds for libraries and education sector

ii. Employment of more qualified staff

iii. Provision of adequate ICT and other educational facilities

iv. Stable power supply

v. Greater government support

vi. Provision of current materials for research and development

vii. Improved appreciation of libraries and education.

viii. Construction of more classrooms among others.

\section{REFERENCES}

[1] Aina, L.O. (2004). Library and information science text for Africa. Ibadan: Sam-Adex Printers Sanyo.

[2] Alumode, B.E. (2013). Education for national transformation: Institutional innovations, challenges and prospects. Unizik Orient Journal of Education, 7 (1), 11-18.

[3] Edom, B.O. (2007). The impact of user education on the use of university libraries in Nigeria. Heartland Journal of Library and Information Science, 1 (1).43-48.

[4] Ejimkonye, C.N., Nwogu, J.E. \& Obiagwu, M.C. (eds.).(2005). Basic librarianship. Owerri: Cel- Bez \& Co. Publishers.

[5] Ezekwe, F.A. \& Muokebe, B.O. (2012).Introductory studies in the use of the library and information technology. Enugu: Rhyce Kerex Publisher,

FRN.(2004). National policy on education. Lagos: NERDC Press.

[6] Ifidon, S.E. \&Ifidon, E.I. (2007).New directions in African library management. Ibadan: Spectrum Books Ltd.

[7] Nwosu, C. (2000). A Textbook in the use of library for higher education. Owerri: Springfield Publishers.

[8] Shah, A. (2012). Sustainable development. http://www.globalissue.org/article/408/sustainable-developmentintroduction.Retrieved on 21st August, 2014. 